\title{
VARIABILITY IN BIOCHEMICAL COMPOSITION OF MILK AMONG THREE REPRESENTATIVE BREEDS OF DAIRY COWS FROM ROMANIA
}

\author{
RADU SILAGHI-DUMITRESCU ${ }^{\mathrm{a}}$, NICOLETA TOMOIAGA ${ }^{\mathrm{a}}$, \\ EUGEN JURCO ${ }^{\mathrm{b}}$
}

\begin{abstract}
Reported here is a comparative analysis of the milk from three representative breeds of dairy cows from Romania - Maramures Brown (Brună de Maramureş), Romanian Spotted (Bălțata Românească) and Black Spotted Romanian (Bălțata cu Negru Românească) - in terms of SDS-PAGE analysis of the protein distribution, total contents of protein, lipids, lactose, dry substance, somatic cell counts, $\mathrm{pH}$ and yield of milk. The Maramures Brown displays the highest percentage of proteins and of dry matter, the lowest yield of milk, the highest amounts of $\alpha$-lactalbumin and $\beta$-lactoglobulin (tied with the Spotted Romanian for the latter) and the lowest serum albumin and immunoglobulin. The Black Spotted Romanian shows the highest yield of milk, the highest content of lactose, the lowest content in lipids and protein and dry matter, the highest content of casein and BSA, and the lowest content of $\alpha$-lactalbumin and immunoglobulin. The Spotted Romanian shows the highest content of lipids, the highest SSC and the highest proportion of lactoferrin. Positive correlations with $r$ values at $0.6-0.8$ are found between the relative contents of various components - $\alpha$ vs. $\beta$ casein, Ig vs. $\alpha$ casein, Ig vs. $\beta \mathrm{Lgb}$, lactoglobulin vs. lactalbumin, $\beta$ casein and $\alpha$ Lac, BSA vs. $\beta$ casein and aLac, total protein content vs. dry residue, SSC vs. lactoferrin and $\beta$ casein. A weak negative correlation is seen between the total lipid content and lactose $(-0.6)$.
\end{abstract}

Keywords: milk, SDS-PAGE, protein, casein, whey

\footnotetext{
a Babes-Bolyai University, Faculty of Chemistry and Chemical Engineering, RO-400028, Cluj-Napoca, Romania.

b University of Agricultural Sciences and Veterinary Medicine RO-400372, Cluj-Napoca, Romania.

* Corresponding author: rsilaghi@chem.ubbcluj.ro
} 


\section{INTRODUCTION}

Of obvious practical interest, chemical variability in milk is traditionally confined to standard compulsory analyses such as yield of milk, total protein content, lactose, $\mathrm{pH}$ and others - with occasional incursions into such details as the variability in protein distribution and/or variability within or among races.[114] In terms of the relative content of various proteins within the milk, the studies are typically confined to a small number of the major proteins (caseins, lactalbumin and lactoglobulin especially), either analyzed qualitatively with gel electrophoresis or, with even narrower focus on variations such as glycosylation and alleles, quantitatively with more advanced chromatographic techniques. Other studies, in terms of genetic variability or of technological parameters (mainly yield of milk) are also available.[1-4,6,8,15]

Of the proteins in whole milk, by far the most abundant ones are the caseins ( $\alpha \mathrm{S} 1, \alpha \mathrm{S} 2, \beta, \mathrm{k}$, all at cca 25-30 kDa and with $\alpha$ and $\beta$ much more abundant than k), $\alpha$-lactalbumin ( $\alpha \mathrm{Lac}, 14 \mathrm{kDa}$ ), and $\beta$-lactoglobulin ( $\beta \mathrm{Lgb}$, $18 \mathrm{kDa}$ ). All other proteins except casein are generally also referred to as whey proteins; these include $\alpha$-lactalbumin and $\beta$-lactoglobulin as the dominant components, plus a number of others among which bovine serum albumin (BSA, $\sim 68 \mathrm{kDa}$ ), lactoferrin ( $\mathrm{Lf}, \sim 80 \mathrm{kDa}$ depending on the degree of glycosylation) and immunoglobulin $\mathrm{A}(\sim 70 \mathrm{kDa}$ for the heavy chain, $\sim 15 \mathrm{kDa}$ for the light chain; other immunoglobulins are at 160-1000 kDa) are typically discussed - though often inconsistently assigned in SDS-PAGE analyses.[1,2,4, 5,8,10-12,15-18]

A number of studies have been reported on the variability of a limited number of components within the milk of dairy cows from a small set of regions (e.g., Holland and European Northern regions, or Bulgaria).[2,4,8] To our knowledge there is not, at this time, a detailed study dedicated to the chemical composition (and variability thereof) in the milk of dairy cows endemic/specific to Romania. The three most common dairy cattle breeds in Romania are Maramures Brown (Bruna, the result of crossing between the Grey Romanian Cattle native breed with Schwyz), Romanian Spotted (Bălțata Românească, the result of crossing between the Grey Romanian Cattle native breed with Simmental bulls) and Black Spotted Romanian (Bălțata cu Negru Românească, evolved more recently from Dobrogean Red, Romanian Spotted and Brown).[9, 13,18] Milk from these breeds is analyzed in the present study in terms of SDS-PAGE analysis of the protein distribution, total contents of protein, lipids, lactose, dry substance, somatic cell counts, $\mathrm{pH}$ and yield of milk. Also reported here is to our knowledge the first example of comparative quantitative SDSPAGE analysis of milk samples from various breeds, as well as an analysis of the correlations between various parameters. 


\section{RESULTS ANS DISCUSSION}

Samples from 15 animals (five each from the respective races Maramures Brown B, Romanian Spotted RS and Black Spotted Romanian BSR), all housed under similar conditions at a farm representative for the northwestern part of Romania (Transylvania) - were analyzed for total contents of protein, lipids, lactose, dry substance, somatic cell counts, $\mathrm{pH}$ as standard parameters assayed in dairy farms. Table 1 shows the average values of these indicators for the three races. At the outset, one may note that the standard deviation values are generally larger than the differences in values among races. Nevertheless, one may note that on average the Brown shows the highest protein content (implicitly the highest content of dry substance) and the lowest content in lactose as well as the lowest yield of milk. The Romanian Spotted shows the highest content of lipids. The Black Spotted Romanian shows the highest content in lactose and the lowest content in lipids and protein alongside the highest yield of milk. The urea and SSC parameters are generally indicative the well-being of the animal (urea for nutrition, SSC for possible infection) - and fall within normal parameters in the present dataset.

Table 1. Average values (with standard deviations in parentheses) for total contents of lipids, protein, lactose, dry residue (excluding lipids) (all expressed in g/100 g), pH, urea $(\mathrm{mg} / \mathrm{mL})$, somatic cell count SCC (per $\mathrm{mL}, \mathrm{x} 1000$ ) and yield of milk (L/session) for the three races (Brown B, Spotted Romanian SR, and Black Spotted Romanian BSR). The complete set of individual values is available as Supporting Information. The lowest and highest values for each parameter are highlighted in bold and grey, respectively.

\begin{tabular}{|c|c|c|c|c|c|c|c|c|}
\hline Race & Lipids & Protein & Lactose & dry & $\mathbf{p H}$ & Urea & SSC & yield \\
\hline B & 4.02 & $\mathbf{3 . 8 8}$ & 4.63 & $\mathbf{9 . 2 8}$ & 6.62 & 4.90 & 71.5 & 6.7 \\
& $(0.66)$ & $\mathbf{( 0 . 2 7 )}$ & $(0.25)$ & $\mathbf{( 0 . 3 0 )}$ & $(0.09)$ & $(2.97)$ & $(38.7)$ & $(1.3)$ \\
\hline BSR & 3.80 & 3.52 & $\mathbf{4 . 8 4}$ & 9.16 & 6.58 & 3.04 & 77.6 & $\mathbf{8 . 9}$ \\
& $(0.69)$ & $(0.26)$ & $\mathbf{( 0 . 1 0 )}$ & $(0.26)$ & $(0.07)$ & $(1.73)$ & $(51.2)$ & $(\mathbf{1 . 0})$ \\
\hline SR & $\mathbf{4 . 1 4}$ & 3.67 & 4.70 & 9.18 & 6.59 & $\mathbf{6 . 9 8}$ & 240.4 & 7.6 \\
& $\mathbf{( 0 . 2 7 )}$ & $(0.35)$ & $(0.11)$ & $(0.33)$ & $(0.08)$ & $\mathbf{( 2 . 9 1 )}$ & $(264.9)$ & $(1.0)$ \\
\hline
\end{tabular}

Figure 1 shows the results of SDS-PAGE measurements of the three types of milk. Using an automated analysis, 14 bands were identified across the 18 lanes of milk in Figure 1 - though not all bands display detectable values in all lanes. Table 2 shows the intensities of the bands, computed from two types of measurements - either from the gels of the three samples each representing mixtures of milk from five animals, or as average of the values measured form gels of each of the respective individuals, per race. 
Based on previous data, $[2-5,15,17]$ one may assign the two most abundant proteins (lanes 8 and 9 amounting to more than $50 \%$ of the protein) to $\alpha$ and $\beta$ casein (calculated MW at 26 and $23 \mathrm{kDa}$, respectively) - with k-casein in lane 10 (calculated MW at $21 \mathrm{kDa}$ ). Regardless of the mode of measurements (whether directly on mixtures of milk from cows of the same breed, or by averaging the values measured individually for each cow of the same breed), Romanian Black Spotted appears to show more casein (especially $\alpha$ ) than the other two races. Next, one may also assign bands 13 and 14 to lactoglobulin ( $\beta \mathrm{Lgb}$, at an apparent $\mathrm{MW}$ of $15 \mathrm{kDa}$ ) and lactalbumin ( $\alpha \mathrm{Lac}, 14 \mathrm{kDa}$ ), respectively. There is a clear trend $\mathrm{B}>\mathrm{BSR}>\mathrm{RS}$ for $\beta \mathrm{Lgb}$ and $B \sim S R>B S R$ for aLac. The remaining proteins are, as discussed above, inconsistently assigned in the literature. As shown in Table 2, we propose to assign lane 4 to BSA (typically the strongest band in the 50-130 kDa range in milk, computed here at $71 \mathrm{kDa}$ ), lane 3 to lactoferrin ( $\mathrm{Lf}, 108 \mathrm{kDa}$ ) and lane 5 to the heavy chain of immunoglobulin A (Ig, $62 \mathrm{kDa}$ ). If so, then BSA appears more abundant in BSR than in the other two races (with RS then slightly higher than B), while RS shows distinctly more Lf than the other two races. The Ig values are very similar across the three races, with BSR showing slightly lower values than the other two.

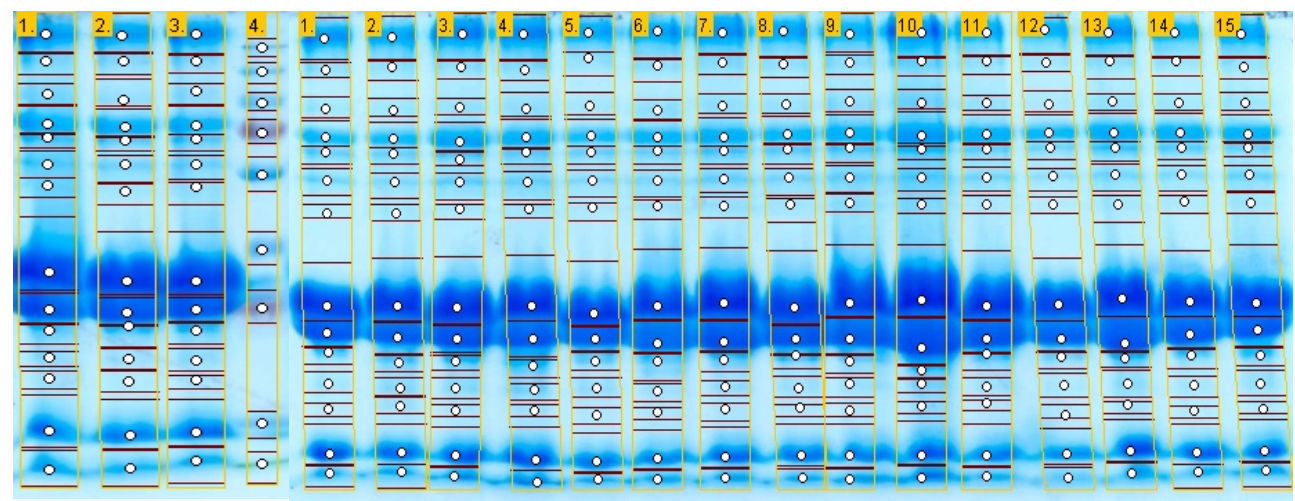

Figure 1. SDS-PAGE gels of milk. The left panel shows samples of equi-volumetric mixtures of the 5 samples of milk from Spotted Romanian (lane 1), Black Spotted Romanian (lane 2), and Brown (lane 3), alongside molecular weight markets (lane 4, with values in $\mathrm{kDa}$ in ascending order as follows: 10, 15, 25, 35, 55, 75, $100,130,250)$. The right panel shows individual samples from the 15 animals (B-1-5, SR - 6-10, BSR - 11-15). 
Table 2. Values for the intensities of the 14 protein bands (shown as percentages of the sum of intensities over each respective lane) in the SDS-PAGE of milk. In each cell, the averages of individual values for the animals of the same race and those measured for mixtures of milk from the five animals of the respective race cf Figure 1 are shown, in this order. Molecular weights (MW) were estimated based on the molecular weight markers indicated in Figure 1 using the fitting function $y=13.095{ }^{*} x^{(-1.173)}$. The complete set of individual values is available as Supporting Information.

\begin{tabular}{|l|c|c|c|c|c|c|c|c|c|c|c|c|c|c|}
\hline Protein & $\mathbf{1}$ & $\mathbf{2}$ & $\mathbf{3}$ & $\mathbf{4}$ & $\mathbf{5}$ & $\mathbf{6}$ & $\mathbf{7}$ & $\mathbf{8}$ & $\mathbf{9}$ & $\mathbf{1 0}$ & $\mathbf{1 1}$ & $\mathbf{1 2}$ & $\mathbf{1 3}$ & $\mathbf{1 4}$ \\
\hline $\mathrm{MW}(\mathrm{kDa})$ & 473 & 186 & 108 & 71 & 62 & 50 & 42 & 26 & 23 & 21 & 19 & 18 & 15 & 14 \\
\hline \multirow{3}{*}{} & 15 & 1.2 & 0.54 & 6.8 & 2.1 & 2.0 & 0.14 & 32 & 19 & 2.5 & 0.65 & 0.07 & 13 & 5.0 \\
& 13 & 1.1 & 0.4 & 6.5 & 1.7 & 1.3 & 0.27 & 32 & 17 & 3.0 & 0.44 & 0.13 & 15 & 7.5 \\
\hline \multirow{3}{*}{$\mathrm{BSR}$} & 12 & 0.8 & 0.44 & 7.6 & 2.0 & 1.4 & 0.16 & 35 & 21 & 2.5 & 0.36 & 0.01 & 12 & 4.6 \\
\hline \multirow{2}{*}{$\mathrm{RS}$} & 11 & 1.4 & 0.5 & 7.3 & 1.4 & 1.6 & 0.14 & 33 & 19 & 3.3 & 0.17 & 0.05 & 14 & 6.9 \\
\hline
\end{tabular}

Table 3 shows correlation coefficients across all the values measured in the present study. A general lack of correlation between the 14 proteins observed in the SDS-PAGE gels can be reconciled with the concept that there is indeed complex variability in terms of protein composition across the races. Some correlations were perhaps expected and are observed as such. For instance, bands 8 and 9 ( $\alpha$ and $\beta$ casein) show a positive correlation coefficient of $\sim 0.8$. For the two key components of whey, $\beta \mathrm{Lgb}$ and $\alpha \mathrm{Lac}$ (lanes 13 and 14), the correlation coefficient is 0.7 . There are also a 0.7 correlation coefficients between $\lg$ and $\alpha$ casein and $\lg$ and $\beta \mathrm{Lgb}$, respectively (plus a slightly weaker correlation, at 0.6 , between $\beta$ casein and aLac. BSA shows correlation with $\beta$ casein (0.7) as well as with aLac (0.6). Also, expectedly, there is positive correlation (0.8) between the total protein content and the dry residue. A weak negative correlation is seen between the total lipid content and lactose $(-0.6)$. The somatic cell count shows a 0.6 correlation coefficient with lactoferrin (to some extent expectedly given their function in defense/immunity) as well as with $\beta$ casein. The amount of milk shows very little correlation with any of the parameters; the highest value, $\sim 0.5$, is seen with BSA.

\section{CONCLUSIONS}

The main three races of local dairy cows from a representative farm in northwestern Romania (Maramures Brown, Spotted Romanian and Black Spotted Romanian) were analyzed in terms of the yield and composition of the milk (SDS-PAGE analysis of the protein distribution, total contents of protein, lipids, lactose, dry substance, somatic cell counts, $\mathrm{pH}$ ). The differences between the races are small but may be summarized as follows. 
The Maramures Brown (Bruna) stands out with the highest percentage of proteins and of dry matter, but the lowest yield of milk. In terms of the percentages of proteins (as determined from SDS-PAGE analyses), this race also shows the highest amounts of $\alpha$-lactalbumin and $\beta$-lactoglobulin (tied with the Spotted Romanian for the latter) but lowest serum albumin and immunoglobulin.

The Black Spotted Romanian (Bălțata cu Negru Românească) shows the highest yield of milk and the highest content of lactose, offset by the lowest content in lipids, protein and dry matter. In terms of relative contributions of the various proteins, BSR shows the highest content of casein and BSA - as opposed to the lowest content of $\alpha$-lactalbumin and immunoglobulin.

The Spotted Romanian (Bălțata Românească) shows the highest content of lipids, the highest SSC and the highest proportion of lactoferrin.

Positive correlations with $r$ values at $0.6-0.8$ are found between the relative contents of various components - $\alpha$ vs. $\beta$ casein, lg vs. $\alpha$ casein, lg vs. $\beta \mathrm{Lgb}$, lactoglobulin vs. lactalbumin, $\beta$ casein and $\alpha \mathrm{Lac}, \mathrm{BSA}$ vs. $\beta$ casein and $\alpha \mathrm{Lac}$, total protein content vs. dry residue, SSC vs. lactoferrin and $\beta$ casein.

Table 3. Correlation coefficients (Pearson's $r$ ) among the Table 1 and Table 2 data measured for the 15 milk samples from the three races (see Supporting Information for individual values of each parameter). The $r$ values at $~ 0.6$ of higher are highlighted.

\begin{tabular}{|c|c|c|c|c|c|c|c|c|c|c|c|c|c|c|c|c|c|c|c|c|c|c|}
\hline & ip & ro & Lac & $y$ & $\mathrm{pH}$ & Ure & SC & 1 & 2 & 3 & 4 & 5 & 6 & 7 & 8 & 9 & 10 & 11 & 12 & 13 & 14 & yield \\
\hline p & S & 0 & 0.58 & 08 & & 21 & 0.16 & 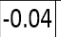 & & 0.35 & -0.46 & & $\mid-0.12$ & 01 & -0.32 & 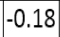 & -0.23 & 0.00 & 0.16 & 0.1 & .03 & 0.2 \\
\hline & 28 & 1.00 & 0.46 & 78 & & 0.01 & 28 & 0.66 & 53 & & 04 & 0.13 & 69 & 40 & 05 & & 0.34 & 0 & $1+$ & 38 & 0.22 & -0.37 \\
\hline $\mathrm{ac}$ & 88 & -1 & 1.00 & 0.20 & 0.52 & -0.49 & -0.20 & -0.31 & 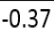 & -0. & 0.03 & 0.00 & 29 & 0.06 & 0.04 & .10 & 0.14 & -0.28 & $0-0.49$ & .47 & $1-0.52$ & 0.30 \\
\hline dry & .08 & 0.78 & 0.20 & 1.00 & 0.28 & -0.40 & -0.42 & 0.53 & 0.37 & -0.21 & 0.07 & 0.14 & 0.55 & 0.42 & -0.02 & -0.45 & 0.49 & 0.34 & -0.2 & 0.09 & -0.1 & -0.20 \\
\hline $\mathrm{pH}$ & -0.54 & -0.10 & 0.52 & 0.28 & 1.00 & -0.29 & 0.10 & 0.34 & 0.12 & 0.33 & 0.33 & 0.39 & 0.34 & -0.18 & -0.01 & 0.06 & 0.32 & -0.08 & -0.2 & 0.04 & -0.0 & 0.05 \\
\hline Ure & 0.21 & 0.01 & -0.49 & -0.40 & $\mid-0.29$ & 1.00 & 0.39 & 0.27 & 0.14 & 0.19 & -0.11 & -0.07 & 0.11 & 0.14 & -0.01 & 0.12 & \begin{tabular}{|l|l|} 
\\
\end{tabular} .04 & $\mid-0.15$ & 0.46 & 0.02 & 0.15 & 0.32 \\
\hline SC & 0.16 & -0.28 & -0.20 & -0.42 & 0.10 & 0.39 & 1.00 & 0.15 & 0.20 & 0.61 & 0.39 & 0.21 & -0.07 & -0.01 & 0.15 & 0.60 & -0.10 & -0.54 & 0.15 & .04 & 0.51 & 0.16 \\
\hline 1 & -0.04 & 66 & 0.31 & 0.53 & 0.34 & 0.27 & 0.15 & 1.00 & 0.66 & 0.22 & 0.40 & 0.50 & 0.81 & 0.38 & 0.26 & 0.10 & 0.54 & 0.21 & -0.16 & 51 & 0. & -0.3 \\
\hline 2 & 25 & 0.53 & -0.37 & 37 & G & 0.14 & 20 & 66 & -2 & 0. & 0.19 & 0.24 & 0. & 0.38 & 0.26 & 0 & 0.09 & 0.36 & 0.13 & 2 & 0. & -0.3 \\
\hline 3 & 0.35 & -0.1 & -0. & .21 & 0.33 & 0.19 & 0.61 & 0.22 & 0.43 & 1.00 & 0.22 & \begin{tabular}{|l|l|} 
\\
\end{tabular} & 0.11 & -0.08 & -0.04 & 0.35 & -0.19 & -0.38 & -0.10 & $\mid-0.6$ & 0.3 & -0.06 \\
\hline 4 & -0.46 & 0.04 & 0.03 & 0.07 & 0.33 & -0.11 & 0.39 & 0.40 & 0.19 & 0.22 & 1.00 & 0.54 & 0.49 & 0.17 & 0.52 & 0.66 & 0.08 & -0.31 & -0.23 & 0.33 & 0.61 & 0.52 \\
\hline 5 & -0.39 & 0.13 & 0.00 & 0.14 & 0.39 & -0.07 & 0.21 & 0.50 & 0.24 & 0.10 & 0.54 & 1.00 & 0.44 & 0.36 & 0.68 & 0.59 & 0.35 & $\mid-0.06$ & -0.18 & 0.73 & 0.4 & -0.24 \\
\hline 0 & -0.12 & 0.69 & -0.2 & 0.55 & 0.34 & 0.11 & -0.07 & 0.81 & 0.45 & 0.11 & 0.49 & 0.44 & 1.00 & 0.08 & 0.05 & -0 & 0.42 & 0.31 & -0.13 & $0.5 /$ & 0.42 & -0.25 \\
\hline 1 & 0.01 & 0.40 & -0.06 & 0.42 & -0.18 & 0.14 & -0.01 & 0.38 & 0.38 & -0.0 & 0.17 & 0.36 & 0.08 & 1.00 & 0.62 & 0.29 & 0.36 & -0.15 & -0.10 & 0.04 & 0. & -0.12 \\
\hline 8 & -0.32 & -0.05 & 0.04 & -0.02 & -0.01 & 0.0 & 0.15 & 0.26 & 0.26 & -0.0 & 0.52 & 0.68 & 0.05 & 0.62 & 1.00 & 0.77 & 0.15 & -0.18 & -0.14 & 0.37 & 0. & 0.10 \\
\hline 9 & -0.18 & -0.36 & 0.10 & -0.45 & 0.06 & 12 & 0.60 & 0.10 & 0.14 & 0.35 & 0.66 & 0.59 & -0. & 0.29 & \begin{tabular}{|l|}
0.77 \\
\end{tabular} & 1.00 & -0.05 & -0.51 & -0.0 & 0.27 & 0. & 0.29 \\
\hline 10 & -0.23 & 34 & 0.14 & 0.49 & 0.32 & 0.0 & 0.10 & 0.54 & 0.09 & -0. & 0.08 & 0.35 & 0.42 & 0.36 & 0.15 & -0.05 & 1.00 & 0.15 & -0.19 & 0.31 & 0.1 & -0.4 \\
\hline 11 & 0.00 & 0.50 & -0.28 & 0.34 & -0.08 & -0.1 & -0.54 & 0.21 & 0.36 & -0.3 & -0.31 & -0.06 & 0.31 & -0.15 & -0.1 & -0.51 & 0.15 & 1.00 & 0.12 & 0.40 & 0.12 & -0.47 \\
\hline 12 & 0.16 & 0.11 & -0.49 & -0.24 & -0.28 & 0.46 & 0.15 & -0.16 & -0.13 & -0.10 & -0.23 & -0.18 & -0.13 & -0.10 & -0.1 & -0.0 & -0.19 & 0.12 & 1.00 & 0.07 & 0.15 & -0.21 \\
\hline 13 & -0.10 & 0.38 & -0.45 & 0.09 & 0.04 & -0.02 & 0.04 & 0.51 & 0.22 & -0.08 & 0.33 & 0.73 & 0.57 & 0.04 & 0.37 & 0.27 & 0.31 & 0.40 & 0.07 & 1.00 & 0.68 & -0.39 \\
\hline 14 & 0.03 & 0.22 & -0.52 & -0.10 & -0.02 & 0.15 & 0.51 & 0.51 & 0.49 & 0.31 & 0.61 & 0.49 & 0.42 & 0.11 & 0.51 & 0.62 & 0.13 & 0.12 & 0.15 & 0.68 & 1.00 & 0.01 \\
\hline ad & 27 & -0.37 & 0.30 & $\mid-0.20$ & -0.05 & -0.32 & 0.16 & -0.31 & -0.31 & -0.06 & 0.52 & -0.2 & 0.2 & -0.12 & 0.10 & 0.29 & -0.41 & -0.47 & -0.21 & -0.33 & 0.01 & 1.00 \\
\hline
\end{tabular}


The highest correlation of the yield of milk is with BSA. A weak negative correlation is seen between the total lipid content and lactose (-0.6). Beyond these, a number of other potential correlations with $r$ values at $+/-0.4-0.5$ may deserve further attention in future studies with larger sets of samples.

Further exploration of the correlations and trends reported in the present study may be warranted, partly considering the relatively large variations within the parameters collected and partly considering the prospective practical applications in terms of potential selection of breeds based on the desired composition of the milk. Such studies, including evaluation of the parameters over time/age/lactation cycle, dependence on nutrition, environmental parameters (including indoor as well as outdoor variables as well as geographical ones) and other factors are currently under way. Such studies are of particular interest given the current crisis of milk in Romania (in terms of yields, number of animals, adaptation of animals to local conditions).[14,19]

\section{EXPERIMENTAL SECTION}

Milk samples from five animals of each race were collected for analysis on the same, day, in November 2017 at the Experimental and Didactic Farm of the University of Agricultural Sciences and Veterinary Medicine at Cojocna, Cluj county, Romania. The animals were fed a uniform standard fodder (mixture of lucerne hey, maize silage and concentrates) under conditions previously described.[14]

For electrophoresis, the milk samples were centrifuged for 10 minutes at $5000 \mathrm{~g}$ in order to remove the lipids, after which $5 \mu \mathrm{L}$ of milk were mixed with $35 \mu \mathrm{L}$ of PBS buffer and $10 \mu \mathrm{L}$ of $5 x$ loading dyes followed by 10 minutes of $90{ }^{\circ} \mathrm{C}$ incubation. A volume of $20 \mu \mathrm{L}$ of the obtained solution was loaded onto a $15 \%$ SDS-PAGE as previously described. After protein migration was complete, the gel was incubated in fixing buffer $(45 \%$ methanol, $45 \%$ water, and $10 \%$ glacial acetic acid) for 10 minutes and then treated with staining solution $(0.1 \%(\mathrm{w} / \mathrm{v})$ Coomassie blue, and 10\% (v/v) acetic acid, $20 \%(\mathrm{v} / \mathrm{v})$ methanol overnight followed by distaining in $50 \%(\mathrm{v} / \mathrm{v})$ methanol, $50 \%(\mathrm{v} / \mathrm{v})$ water with $10 \%(\mathrm{v} / \mathrm{v})$ acetic acid.[1,20] The SDS-PAGE gels were analyzed using the Gel Analyzer 2010a software (gelanalyzer.com).

The total contents of protein, lipids, lactose, dry substance, somatic cell counts and $\mathrm{pH}$ were determined by standard procedures as previously described.[6,9]

Supporting Information is available from the authors upon request (Table S1 - Individual values for total contents of components, Table S2 - Individual values of intensities/weights of the bands identified in the SDS-PAGE analyses, Figure S1 and Figure S2- Band profiles of the lanes in Figure 1). 


\section{ACKNOWLEDGEMENTS}

Drs. Marioara Moldovan and Augustin C. Moț (BBU) are thanked for helpful discussions.

\section{REFERENCES}

1. D. Prodan, M. Filip, M. Moldovan, I. Perhaita, F. Scurtu, L. Silaghi-Dumitrescu, A. Dreanca, I. Marcus, Journal of Environmental Protection and Ecology, 2018, in press.

2. A.K. Rosengaard, Aarhus University, 2016.

3. F.F. Costa, M.A.V.P. Brito, M.A.M. Furtado, M.F. Martins, M.A.L. De Oliveira, P.M. Barra, L.A. de C. Garridoc, A.S. Dos Santos, Analytical Methods, 2014, 1666.

4. L. Zagorchev, M. Dimitrova, M. Odjakova, D. Teofanova, P. Hristov, Bulgarian Journal of Agricultural Sciences, 2013, 19, 197.

5. S. Jovanovic, M. Barac, O. Macej, T. Vucic, C. Lacnjevac, Sensors, 2007, 7, 371.

6. V.A. Balteanu, Bulletin UASVM Animal Science and Biotechnolologies, 2011, 68, 71.

7. S.E. Georgescu, M.A. Manea, Z. Mihaela, M. Costache, Romanian Biotechnological Letters, 2009, 14, 4194.

8. R.A. Vătăsescu-Balcan, S.E. Georgescu, M.A. Manea, A. Dinischiotu, C.D. Tesio, M. Costache, Zootehnie si Biotehnologie, 2008, 41, 169.

9. G. Muresan, E. Jurco, S. Cărcu, C. Pop, Sci. Pap. Ser. Manag. , Economic Engineering Agric Rural Development, 2013, 13, 245.

10. F. Liu, M. Teodorowicz, M.A. van Boekel, H.J. Wichers, K.A. Hettinga, Food and Function, 2016, 7, 239

11. A. Nikkhah, Journal of Nutrition and Food Science, 2011, 1, 1000116.

12. E. Rojas, G. Torres, Food Science and Technology, 2013, 33, 14.

13. G. Onaciu, E.C. Jurco, L. Ognean, Bulletin UASVM Animal Science and Biotechnology, 2014, 71, 250.

14. E.C. Jurco, G. Onaciu, Z. Marchis, L. Ognean, Bulletin UASVM Animal Science and Biotechnology, 2016, 73, 243-244.

15. C.C. Chen, S.T. Chen, J.F. Hsieh, Molecules, 2015, 20, 7737-7749.

16. Neelima; R. Sharma, Y.S. Rajput, B. Mann, Dairy Science Technology, 2013, 93, 21.

17. W.L. Hurley, 2009, Available at: http://ansci.illinois.edu/static/ansc438/Milkcompsynth/ milksynth_proteinbiochem.html. (Accessed: 7th January 2018)

18. C. Velea, G. Marginean, G., Tratat de cresterea bovinelor, vol. 1, Editura Risoprint, 2012.

19. A. Popescu, Sci. Pap. Ser. Manag. Econ. Eng. Agric. Rural Dev., 2017, 17, 281.

20. M. Arkosi, F. Scurtu, A. Vulpoi, R. Silaghi-Dumitrescu, D.M. Kurtz Jr., Artificial Cells Blood Substitutes Biotechnology, 2017, 45, 218-223. 